\title{
THE UNITED STATES AND \\ THE METRIC SYSTEM
}

\section{A Capsule History}

The United States is the only industrialized country in the world not officially using the metric system. Because of its many advantages (e.g., easy conversion between units of the same quantity), the metric system has become the internationally accepted system of measurement units.

Most Americans think that our involvement with metric measurement is relatively new. In fact, the United States' increasing use of metric units has been underway for many years, and the pace has accelerated in the past two decades. In the early 1800's the U.S. Coast and Geodetic Survey (the government's surveying and map-making agency) used meter and kilogram standards brought from France. In 1866 Congress authorized the use of the metric system in this country and supplied each state with a set of standard metric weights and measures.

In 1875, the United States reinforced its participation in the development of the internationally recognized metric system by becoming one of the original seventeen signatory nations to the Treaty of the Meter. This agreement established the International Bureau of Weights and Measures (BIPM) in Sèvres, France, to provide standards of measurement for worldwide use.

In 1893, the metric measurement standards, resulting from international cooperation under the auspices of BIPM, were adopted as the fundamental standards for length and mass in the United States. Our "customary" measurements - the foot, pound, quart, etc., - have been defined in relation to the meter and the kilogram ever since.

In 1960, the General Conference of Weights and Measures, the governing body that has overall responsibility for the metric system, and which is made-up of signatory nations to the Treaty of the Meter, approved a modernized version of the metric system. The "modernized" system is called Le Systeme International d'Unites or the International System of Units, abbreviated SI.

In 1965, Great Britain, as a condition for becoming a member of the European Common Market, began a transition to the metric system in its trade and commerce. The conversion of England and the Commonwealth Nations to SI created a new sense of urgency regarding the use of metric units in the United States. Congress authorized a three-year study of this Nation's systems of measurement, with particular emphasis on the feasibility of adopting SI. Known as the "Metric Study Act of 1968," the study was conducted by the Department of Commerce. As part of the study, an advisory panel of 45 representatives consulted with and took testimony from hundreds of consumers, business organizations, labor groups, manufacturers, and state and local officials. The panel's report, "A Metric America, A Decision Whose Time Has Come," concluded that measurement in the United States was already based on metric units in many areas and that it was becoming more so every day. The majority of participants in the study believed that conversion to the metric system was in the best interests of 
the Nation, particularly in view of the increasing importance and influence of technology in American life and our foreign trade.

The study recommended that the United States change to predominant use of the metric system over a ten-year period. Congress passed the Metric Conversion Act in 1975. The stated purpose of the Act was "to coordinate and plan the increasing use of the metric system in the United States."

A process of voluntary conversion was initiated with the establishment of the U.S. Metric Board. The Board was charged with "devising and carrying out a broad program of planning, coordination, and public education, consistent with other national policy and interests, with the aim of implementing the policy set forth in this Act." However, the Act did not specify the ten-year conversion period recommended by the study. Further, much of the American public ignored the efforts of the Metric Board. In 1981, the Board reported to Congress that it lacked the necessary clear Congressional mandate to bring about National conversion to predominant use of metric measurements.

Because of the Board's apparent ineffectiveness and efforts to reduce Federal spending, it was disestablished in the fall of 1982 .

The Board's demise increased doubts about the United States' commitment to metrication. Public and private sector metric transition slowed at the same time that the very reasons for the United States to adopt the metric system-the increasing competitiveness of other nations and the demands of global marketplaces-made completing United States metric conversion even more important.

Congress, recognizing the criticality of the United States' conformance with international standards for trade, included new strong incentives for United States industrial metrication in the Omnibus Trade and Competitiveness Act of 1988. That legislation designated the metric system as the "preferred system of weights and measures for United States trade and commerce." It also required that all federal agencies use the metric system in their procurement, grants and other businessrelated activities by a "date certain and to the extent economically feasible, by the end of fiscal year 1992."

The Act's mandates are based on the conclusion that industrial and commercial productivity, effectiveness in mathematics and science education, and competitiveness of American products in world markets, will be enhanced by completing the change to the metric system of units. Failure to do so will increasingly handicap the Nation's industry and economy. The Federal Government's mandate is intended to encourage United States producers to develop their ability to provide goods and services expressed in metric units. 


\section{QUESTIONS AND ANSWERS}

Q. What is the metric system?

A. The metric system is a decimal-based system of measurement units. Like our monetary system, units for a given quantity (e.g., length) are related by factors of 10 . Calculations involve the simple process of moving the decimal point to the right or to the left.

Q. Is the metric system hard to learn and use?

A. There are only seven basic units in the metric system. In everyday usage the most common units are the meter $(\mathrm{m})$ to measure length, the kilogram (kg) for mass (or weight*), the liter (L) for volume, and degree Celsius $\left({ }^{\circ} \mathrm{C}\right.$ ) for temperature. The metric system avoids confusing dual-use of terms, such as our current use of ounces to measure both weight and volume. * While the term "weight" is commonly used for mass, weight is actually the force exerted on a body by gravity. That is why objects that have mass are said to be "weightless" when in space and there are no effects of gravity.

Q. Will "thinking metric" be difficult?

A. Not really. For example, "thinking metric" when using degrees Celsius means associating 20 degrees Celsius $\left(20^{\circ} \mathrm{C}\right)$ with room temperature, 37 degrees Celsius $\left(37^{\circ} \mathrm{C}\right)$ with body temperature and 0 and 100 degrees Celsius with the freezing and boiling points of water, respectively. A millimeter $(1 \mathrm{~mm})$ is about the thickness of a dime and a centimeter $(1 \mathrm{~cm})$ about the width of your thumb nail. Almost everyone already recognizes $1 \mathrm{~L}$ and $2 \mathrm{~L}$ soft-drink bottles. When you pick up a two-pound bag of sugar, you are holding a little less than one kilogram.

Q. Who decided the United States should convert to the metric system?

A. No one "decided the United States should go metric." As stated in the amended Metric Conversion Act, continued use of "traditional systems of weights and measures" is still permitted "in nonbusiness activities." However, metric use has become widespread throughout our economy. Consumers may be surprised at the number of items in everyday use that have been manufactured in metric units for some time, and have been accepted without difficulty. These include photographic equipment, automobiles, much farm and construction equipment, computers, pharmaceutical products, wine and distilled spirits, and soft drinks. Also, our scientific and medical communities use metric units almost exclusively.

Q. Is there a deadline for conversion?

A. No deadline has been established. Congress considered whether conversion should be mandatory; voluntary and planned; or voluntary and unplanned. Congress chose the volu ntary and planned approach in the Metric Conversion Act of 1975 , but set no specific time period for the conversion. The Omnibus Trade \& Competitiveness Act of 1988 amended the 1975 law by making the metric system the "preferred system of weights and measu res for United States trade and commerce" and charged federal agencies with converting to the metric system to the degree economically feasible by the end of fiscal year 1992.

Q. What is voluntary conversion?

A. Individual groups and industries decide whether or not to convert and determine conversion timetables according to their own needs.

Q. Why should the United States convert to the metric system?

A. Since trade with other nations is critical to the health of our economy, adoption of the measurement system used world-wide is not a matter of choice, but a matter of necessity for United States industry. 
Q. Why didn't we convert before?

A. Support for a decimal-based measuring system has existed since the 1700's. However, there was no compelling reason to switch because of our geographical isolation and because our principal trading partner, England, did not use metric units. In time the United States became a dominant force in world trade and was able to impose its products, manufactured in their unconventional units, on other nations. Times have changed. We no longer overwhelmingly dominate world trade and must recognize the need to "fit" our goods and services into other strong markets, including the European Common Market, the new markets of Eastern Europe, and the expanding market of the Pacific Rim. These markets are increasing their preference for metric-sized products.

Q. Will conversion benefit the consumer?

A. Increased industry use of the metric system is expected to promote more standardized and simpler product packaging. Reducing the vast number of package sizes will simplify price comparisons and save on packaging and shipping costs. Resulting savings will reach the consumer. Metric conversion is also expected to make commerce and industry more efficient and the teaching, and learning, of measurement much easier. United States products will also sell better in foreign countries. For all these reasons metric changeover should be good for our economy and for all our citizens.

\section{Q. Will conversion be costly?}

A. Costs will vary in different sectors of the economy. However, in all areas, long term benefits will be realized and will more than offset one-time conversion costs. Many industries are converting as they develop new products and as older equipment wears out. In this way conversion costs can be held to a minimum. Many companies have found that actual costs of conversion are considerably less than expected and can be recovered by expansion of exports, and through product simplification and standardization.
Q. What is government doing about metric conversion?

A. All of the major federal agencies have established plans and internal task forces for managing their change to the metric system as called for in the 1988 Trade Act and a 1991 Presidential Executive Order. The General Services Administration has begun the process of establishing metric specifications for products that it buys for federal agencies. The Defense Department increasingly uses metric specifications in procurement and in activities involving allies around the world. All new NASA projects will be designed and built to metric specifications. The Commerce Department's Metric Program Office works with the member agencies of the Federal Interagency Council on Metric Policy (ICMP) to identify and help remove barriers that may stand in the way of metric conversion in federal and state or local rules, standards and codes, or regulations.

Q. Will everything eventually "go metric?"

A. Adoption of metric units in our social environment will evolve as it becomes economically and socially logical. For example, one can see no merit in changing U.S. football field measurements from yards to meters. On the other hand, track and field events are now measured more often in metric units because of the international nature of competition in that sport. The "rulles of reason" will apply.

For More Information Contact:

Metric Program

National Institute of Standards and Technology

Technology Administration

U.S. Department of Commerce

Gaithersburg, MD 20899

(301) $975-3690$ 
11

Metric

Chocolate

Chip Cookies"

Recipe reprinted from "Living With Metrics" courtesy of Reader's Digest Association, Inc., Pleasantville, New York.

$\begin{array}{rl}550 \mathrm{~mL} & \text { unsifted flour } \\ 5 \mathrm{~mL} & \text { baking soda } \\ 5 \mathrm{~mL} & \text { sait } \\ 250 \mathrm{~mL} & \text { butter or margarine, softened } \\ 175 \mathrm{~mL} & \text { granulated sugar } \\ 175 \mathrm{~mL} & \text { firmly packed brown sugar } \\ 5 \mathrm{~mL} & \text { vanilla extract } \\ 2 & \text { eggs } \\ 2 & 168 \text { gram packages semisweet } \\ & \text { chocolate chips } \\ 250 \mathrm{~mL} & \text { chopped nuts }\end{array}$

Preheat the oven to $190^{\circ} \mathrm{C}$. In small bowl, combine flour, baking soda, and salt; set aside. In large

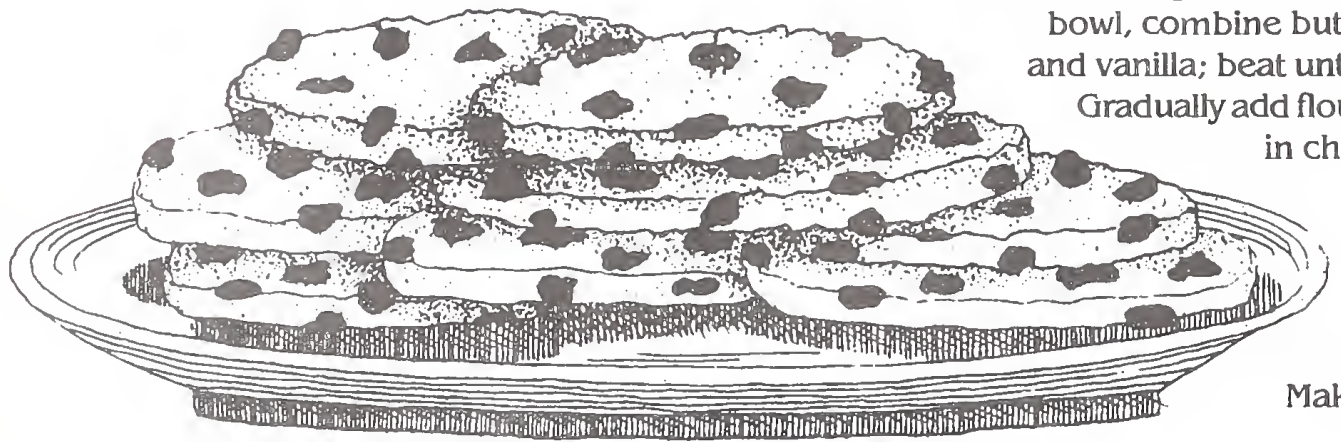
and vanilla: beat until creamy. Beat in egas. Gradually add flour mixture; mix well. Stir in chocolate chips and nuts. Using $5 \mathrm{~mL}$ measure, drop by rounded measures onto ungreased cookie sheet. Bake 8 to 10 minutes. Makes $1005 \mathrm{~cm}$ cookies.

Liquid and Dry Measure Equivallencies *

\begin{tabular}{|c|c|c|}
\hline Customary & Metri & \\
\hline $1 / 4$ teaspoon & 1.25 & milliliters \\
\hline $1 / 2$ teaspoon & 2.5 & milliliters \\
\hline 1 teaspoon & 5 & milliliters \\
\hline 1 tablespoon & 15 & milliliters \\
\hline If fluid ounce & 30 & milliliters \\
\hline $1 / 4$ cup & 60 & milliliters \\
\hline $1 / 3$ cup & 80 & milliliters \\
\hline $1 / 2$ cup & 120 & milliliters \\
\hline 1 cup & 240 & milliliters \\
\hline 1 pint ( 2 cups) & 480 & milliliters \\
\hline $\begin{array}{l}1 \text { quart (4 cups, } \\
32 \text { ounces) }\end{array}$ & 960 & $\begin{array}{l}\text { milliliters } \\
\text { (0.96 liters) }\end{array}$ \\
\hline 1 gallon (4 quarts) & 3.84 & liters \\
\hline 1 ounce (by weight) & 28 & grams \\
\hline $1 / 4$ pound ( 4 ounces) & 114 & grams \\
\hline 1 pound (16 ounces) & 454 & grams \\
\hline 2.2 pounds & 1 & kilogram (1000 grams) \\
\hline
\end{tabular}

Oven Temperature Equivalencies

\begin{tabular}{lll} 
Description & \multicolumn{1}{c}{${ }^{\circ} \mathbf{F}$} & ${ }^{\circ} \mathbf{C}$ \\
\hline Cool & 200 & 90 \\
Very slow & 250 & 120 \\
Slow & $300-325$ & $150-160$ \\
Moderately slow & $325-350$ & $160-180$ \\
Moderate & $350-375$ & $180-190$ \\
Moderately hot & $375-400$ & $190-200$ \\
Hot & $400-450$ & $200-230$ \\
Very hot & $450-500$ & $230-260$
\end{tabular}

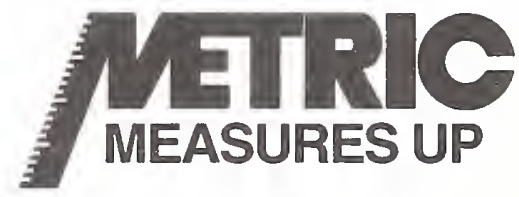

U.S. DEPARTMENT OF COMMERCE TECHNOLOGY ADMINISTRATION 


\section{METRIC CONVERSION CARD}

Approximate Conversions to Metric Measures

\begin{tabular}{|c|c|c|c|c|}
\hline mbol & \multicolumn{3}{|c|}{ LENGTH } & $y m b o l$ \\
\hline in & inches & 2.5 & centimeters & $\mathrm{cm}$ \\
\hline $\mathrm{ft}$ & feet & 30 & centimeters & $\mathrm{cm}$ \\
\hline yd & yards & 0.9 & meters & $\mathrm{m}$ \\
\hline mi & miles & 1.6 & kilometers & $\mathrm{km}$ \\
\hline \multicolumn{5}{|c|}{ AREA } \\
\hline in $^{2}$ & square inches & 6.5 & square centimeters & $\mathrm{cm}^{2}$ \\
\hline $\mathrm{ft}^{2}$ & square feet & 0.09 & square meters & $\mathrm{m}^{2}$ \\
\hline $\mathrm{yd}^{2}$ & square yards & 0.8 & square meters & $\mathrm{m}^{2}$ \\
\hline $\mathrm{mi}^{2}$ & square miles & 2.6 & square kilometers & $\mathrm{km}^{2}$ \\
\hline & acres & 0.4 & hectares & ha \\
\hline \multicolumn{5}{|c|}{ MASS (weight) } \\
\hline $\mathrm{OZ}$ & ounces & 28 & grams & $\mathrm{g}$ \\
\hline $\mathrm{lb}$ & pounds & 0.45 & kilograms & $\mathrm{kg}$ \\
\hline & $\begin{array}{l}\text { short tons } \\
(2000 \mathrm{lb})\end{array}$ & 0.9 & metric ton & $\mathrm{t}$ \\
\hline
\end{tabular}

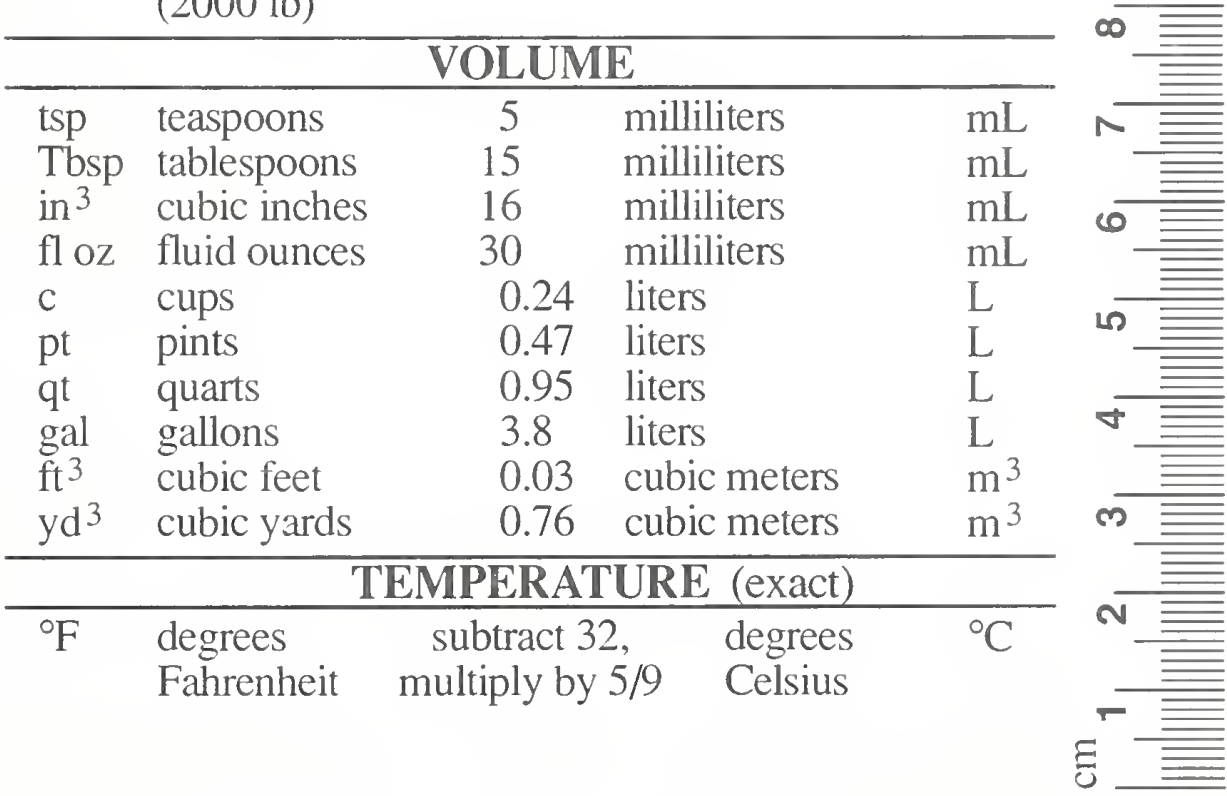




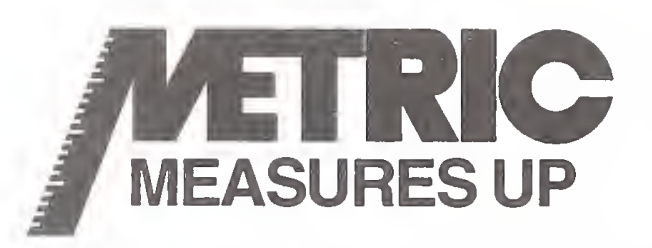

U.S. DEPARTMENT OF COMMERCE TECHNOLOGY ADMINISTRATION

Office of Metric Programs

Washington, D.C. 20230

Approximate Conversions from Metric Measures

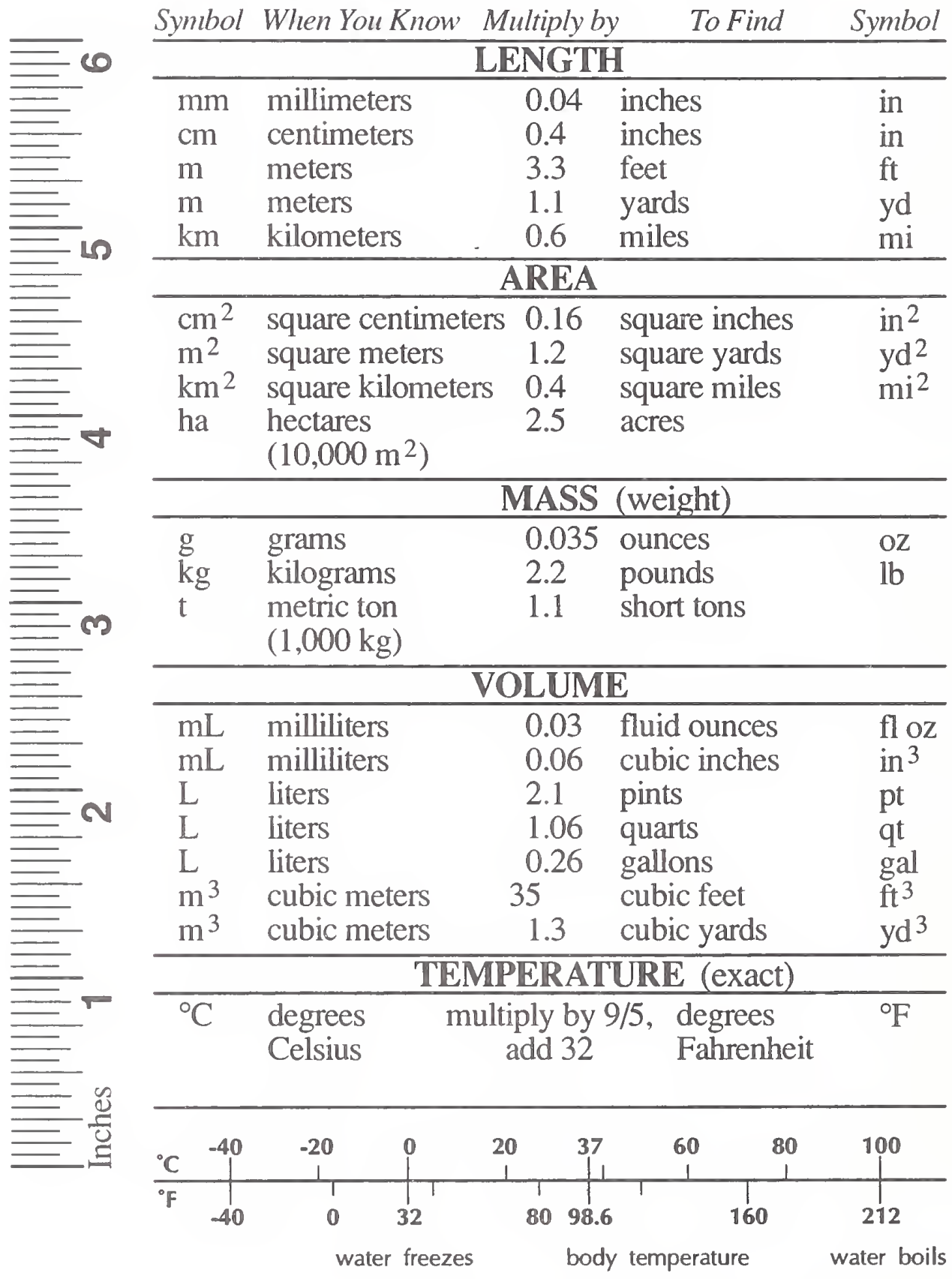




\section{MTRIC \\ National Institute of Standards and Technology \\ Metric Program, Gaithersburg, MD 20899 (For Your Everyday Life)

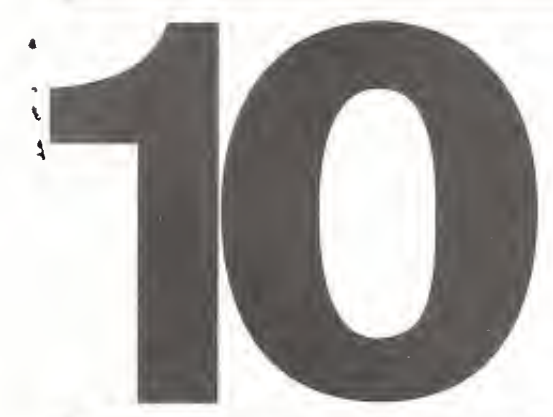

\section{Metric is based on the Decimal system}

The metric system is simple to learn. For use in your everyday life you will need to know only ten units. You will also need to get used to a few new temperatures. Of course, there are other units which most persons will not need to learn. There are even some metric units with which you are already familiar; those for time and electricity are the same as you use now.

\section{BASIC UNITS}

METER: a little longer than a yard (about 1.1 yards) LITER: a little larger than a quart (about 1.06 quarts) GRAM: a little more than the weight of a paper clip
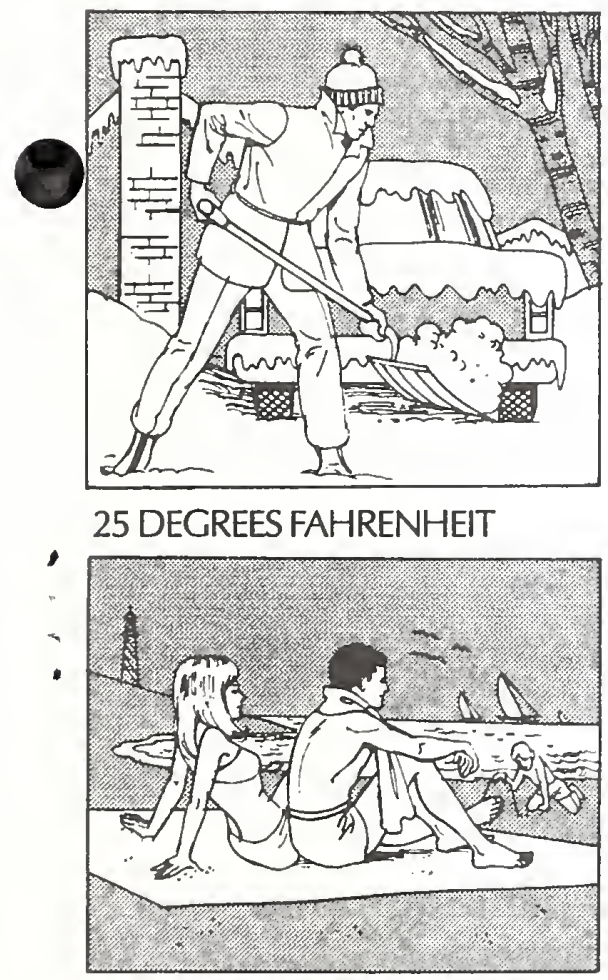

25 DEGREES CELSIUS

For example

\section{COMMON PREFIXES}

(to be used with basic units)

milli: one-thousandth $(0.001)$

centi: one-hundredth $(0.01)$

kilo: one-thousand times (1000)

1000 millimeters $=1$ meter

100 centimeters $=1$ meter

1000 meters $=1$ kilometer

\section{OTHER COMMONLY USED UNITS}

1 LITER

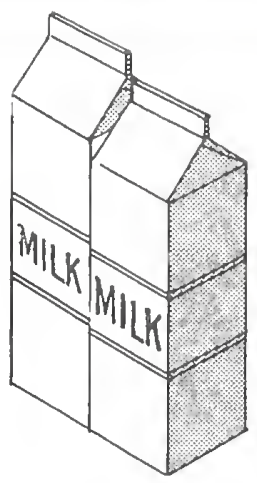

1 QUART

millimeter: 0.001 meter

diameter of a paper clip wire

centimeter: 0.01 meter

a little more than the width of a paper

clip (about 0.4 inch)

kilometer: 1000 meters somewhat further than $1 / 2$ mile (about 0.6 mile)

kilogram: 1000 grams a little more than 2 pounds (about 2.2 pounds)

milliliter: $\quad 0.001$ liter

five of them make a teaspoon

\section{OTHER USEFUL UNITS}

hectare: about 2 1/2 acres metric ton: about one ton

\section{FOR TEMPERATURE degrees celsius \\ WEATHER UNITS:}

FOR PRESSURE

kilopascals are used

100 kilopascals $=29.5$ inches of $\mathrm{Hg}(14.5 \mathrm{psi})$

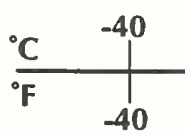

$$
\begin{gathered}
-20 \\
1 \\
0
\end{gathered}
$$
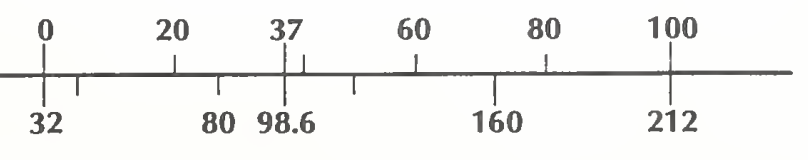

water freezes

body temperature

water boils
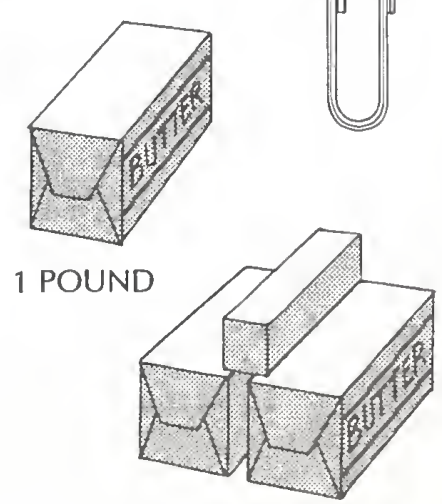

1 KILOGRAM

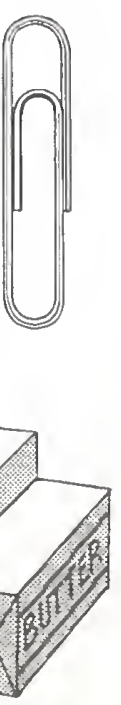




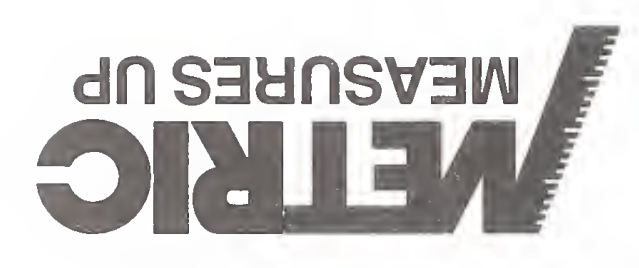

\section{METRIC PUBLICATIONS AVAILABLE FOR SALE BY SUPERINTENDENT OF DOCUMENTS \\ U.S. GOVERNMENT PRINTING OFFICE \\ WASHINGTON, DC 20402}

"METRIC RULER," NIST SP* 376

GPO Stock \# 003-003-03089-9

$\$ 28 / 100$ copies or

$\$ 1.00$ ea

"METRIC CONVERSION CARD," NIST SP* 365

GPO Stock \# 003-003-03090-2

"METRIC CHART," NIST SP* 304

GPO Stock \# 003-003-03096-1

$\$ 2.00$ ea

"BRIEF HISTORY OF MEASUREMENT SYSTEMS WITH A CHART OF THE MODERNIZED METRIC SYSTEM," NIST SP* 304A

GPO Stock \# 003-003-02747-2

"THE INTERNATIONAL SYSTEM OF UNITS (SI)," NIST SP* 330

GPO Stock \# 003-003-03099-6

$\$ 3.50$ ea

"INTERPRETATION OF THE SI FOR THE UNITED STATES AND METRIC CONVERSION

POLICY FOR FEDERAL AGENCIES," NIST SP* 814

GPO Stock \# 003-003-03117-8 